Article

\title{
Predicting Microhabitat Suitability for an Endangered Small Mammal Using Sentinel-2 Data
}

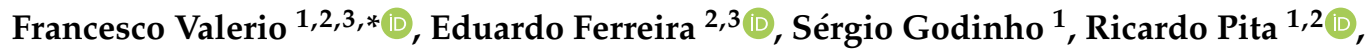 \\ António Mira ${ }^{1,3}{ }^{\circledR}$, Nelson Fernandes ${ }^{3}$ and Sara M. Santos ${ }^{1,3}$ \\ 1 MED—Mediterranean Institute for Agriculture, Environment and Development, Instituto de Investigação e \\ Formação Avançada, Universidade de Évora, Pólo da Mitra, Ap. 94, 7006-554 Évora, Portugal; \\ sgodinho@uevora.pt (S.G.); rpita@uevora.pt (R.P.); amira@uevora.pt (A.M.); smsantos@uevora.pt (S.M.S.) \\ 2 CIBIO-UE, Research Centre in Biodiversity and Genetic Resources. Pole of Évora/InBIO-Research Network \\ in Biodiversity and Evolutionary Biology, University of Évora. Mitra, 7002-554 Évora, Portugal; \\ ferreira@uevora.pt \\ 3 UBC, Conservation Biology Lab, Department of Biology, University of Évora. Mitra, 7002-554 Évora, \\ Portugal; nelsonhf@uevora.pt \\ * Correspondence: fvalerio@uevora.pt or franval.bio@gmail.com
}

Received: 18 January 2020; Accepted: 6 February 2020; Published: 8 February 2020

\begin{abstract}
Accurate mapping is a main challenge for endangered small-sized terrestrial species. Freely available spatio-temporal data at high resolution from multispectral satellite offer excellent opportunities for improving predictive distribution models of such species based on fine-scale habitat features, thus making it easier to achieve comprehensive biodiversity conservation goals. However, there are still few examples showing the utility of remote-sensing-based products in mapping microhabitat suitability for small species of conservation concern. Here, we address this issue using Sentinel-2 sensor-derived habitat variables, used in combination with more commonly used explanatory variables (e.g., topography), to predict the distribution of the endangered Cabrera vole (Microtus cabrerae) in agrosilvopastorial systems. Based on vole surveys conducted in two different seasons over a 176,000 ha landscape in Southern Portugal, we assessed the significance of each predictor in explaining Cabrera vole occurrence using the Boruta algorithm, a novel Random forest variant for dealing with high dimensionality of explanatory variables. Overall, results showed a strong contribution of Sentinel-2-derived variables for predicting microhabitat suitability of Cabrera voles. In particular, we found that photosynthetic activity (NDI45), specific spectral signal (SWIR1), and landscape heterogeneity (Rao's Q) were good proxies of Cabrera voles' microhabitat, mostly during temporally greener and wetter conditions. In addition to remote-sensing-based variables, the presence of road verges was also an important driver of voles' distribution, highlighting their potential role as refuges and/or corridors. Overall, our study supports the use of remote-sensing data to predict microhabitat suitability for endangered small-sized species in marginal areas that potentially hold most of the biodiversity found in human-dominated landscapes. We believe our approach can be widely applied to other species, for which detailed habitat mapping over large spatial extents is difficult to obtain using traditional descriptors. This would certainly contribute to improving conservation planning, thereby contributing to global conservation efforts in landscapes that are managed for multiple purposes.
\end{abstract}

Keywords: remote sensing; species distribution models; habitat metrics; wildlife conservation; rare species; Cabrera vole 


\section{Introduction}

Anthropogenic activities, concurrently with human population growth, are responsible for wiping out wildlife species at rates never experienced before [1]. In particular, agricultural intensification and infrastructure proliferation (roads, railways, etc.), which are considered among the main causes of habitat loss/fragmentation and populations declines, have been rapidly rising to an alarmingly level worldwide [2,3]. Traditionally, wildlife conservation priorities have been focused on megafauna, since species with a large body size have been associated with high extinction risks [4]. However, small body size can also be an important extinction driver [5], possibly exacerbated by species limiting ecological traits (e.g., short dispersal distances), restricted, and/or fragmented distribution and habitat specialization [6].

The Cabrera vole (Microtus cabrerae) is an Iberian-endemic small mammal, classified as "Vulnerable" in Portugal and Spain [7,8], and as "Near-threatened" by IUCN [9]. Within its restricted distribution range, the species presents a fragmented distribution [10], typically associated with marginal areas of agricultural systems, with local populations largely restricted [10-12] to sparse patches of tall and dense wet grasslands [11,13]. The major threats for this species include agriculture and grazing intensification [14], which destroy its preferred habitats, forcing individuals to disperse and occupy small habitat patches (often $<500 \mathrm{~m}^{2}$ [14]) like field margins or road verges $[12,15,16]$. The Cabrera vole often presents a metapopulation-like spatial structure, which together with the regular destruction and turnover of suitable habitat patches, makes the designation of special areas of conservation for this species a particularly challenging task. The designation of these conservation areas is however demanded by the European Union, as the species is listed in both Bern Convention (Appendix II; 82/72/CEE) and Habitats Directive (Annexes II and IV; Council Directive 92/43/EEC). The selection of those key areas should be supported by detailed and up-to-date species' distribution at multiple scales, and the use of efficient tools and frameworks able to appropriately identify them [17]. In this context, correlative species distribution models (SDMs), or habitat suitability/niche models [18], which provide probabilistic estimation of occurrence patterns over broad areas by relating species occurrences with environmental characteristics [18], have become a popular tool to develop potential species range maps.

Numerous studies have extensively reported the utility of SDMs for addressing a variety of ecological questions [19-21], related to biodiversity monitoring and conservation planning [17,22,23], including for the Cabrera vole [10,24]. Yet, SDMs applications on Cabrera voles, or other small and elusive species, at a local or regional scale are still challenging, likely due to their low detectability and/or narrow distribution, which may complicate data collection [25,26]. Moreover, the integration of fine grain habitat requirements for which suitability may change within short time periods makes SDM' building another challenging task, due to the lack of spatially explicit predictor variables able to capture habitat characteristics at small scales [27], as well as to account for species occupancy turnover and landscape dynamism [28], the latter being markedly pronounced in Mediterranean-type ecosystems $[12,29,30]$. Specifically, most available digital habitat proxy information (e.g., land cover/use maps) have low detail precision and have a static time nature (they are not expected to vary within the year) $[28,31]$, and thus may fail to provide relevant ecological information for small species inhabiting dynamic habitat patch networks.

We used Cabrera vole as a model to create up-to-date spatially and temporally detailed habitat suitability maps for species with fine-scale habitat requirements occurring in dynamic landscapes. Opportunities to do this come from Earth Observation Satellites (EOS) due to their multispectral and systematic characteristics, which allows the identification of the vegetation composition and structure, as well as its physiological condition [32-34]. The usefulness of remote-sensing data for species habitat suitability mapping has been reported in numerous studies, as outlined in the review by $\mathrm{He}$ et al. [27]. In this review, the spatial-continuous nature and the reasonable time frequency of satellite-based data are highlighted as an added value to overcome SDMs limitations. By integrating this high-quality data into SDMs, their accuracy can be effectively increased as availability of resources may be better described [28,35-37]. Moreover, remote-sensing data can be used for modelling changes 
in species distribution across time and understand how vegetation changes might affect patch quality and influence demographic parameters, including reproduction and dispersal movements [28].

While it may be straightforward to map habitat suitability areas, for example, for large mammal species [35,38], having broad-scale home range sizes (e.g., $>1000 \mathrm{~m}^{2}$ ), modelling species responding to fine-scale landscape requirements (e.g., small mammals or insects) is challenging from the remote-sensing perspective due to limitations associated to conventional imageries when identifying local resource patches $[38,39]$. Indeed, until recently, the available information from remote sensing (e.g., land-cover) was too coarse or too expensive to be properly applied on fine-scale modelling [28]. The Copernicus Program from the European Commission (EC) in partnership with the European Space Agency (ESA) has been developing several satellite missions under the scope of the Sentinel program [40]. Within this program, a constellation of two multi-spectral satellites called Sentinel-2A (launched on 23 June 2015) and Sentinel-2B (launched on 7 March 2017) are together collecting information at high spatial (up to $10 \mathrm{~m}$ ), spectral (13 bands), radiometric (12 bits), and temporal (each five days) resolution [41]. Due to its technical features and the open data policy, Sentinel-2 brings new opportunities and capabilities for evaluating wildlife spatio-temporal response to habitat features [27] and dynamic processes [36], which may be of particular importance for SDMs developed for small species inhabiting dynamic systems (e.g., grasslands [42]) such as the Cabrera vole. To the best of our knowledge, modelling fine-scale habitat suitability for wildlife conservation, specifically with open-access remote-sensing data and with Sentinel-2 imagery, is still scarce in the literature. Besides, as Sentinel-2 derived-products mostly reflect biotic environmental attributes, the integration of these variables with abiotic descriptors (e.g., topography) into SDMs likely provide more realistic results than using each type of variables alone $[28,36,43]$.

Therefore, by taking advantage from spectral, temporal, and spatial characteristics of Sentinel-2 sensors, the main goal of this study is to assess the usefulness of Sentinel-2 derived predictors for identifying suitable microhabitats for small and elusive species of conservation concern, using the Cabrera vole in a Mediterranean ecosystem as a model. In particular, we aimed to:

i. Quantify the importance of Sentinel-2 derived predictors relative to more conventional predictors

(e.g., topographical and distance to landscape elements) in predicting vole microhabitat suitability;

ii. Identify which Sentinel-2 derived predictors best explain vole distribution at fine spatial scales.

Overall, we predict that Sentinel-2-based variables should provide an important contribution for improving fine-scale habitat mapping of endangered small species, such as the Cabrera vole, thus supporting the view that remote-sensing products should greatly contribute for conserving biodiversity associated to small marginal areas in human-dominated landscapes. For this purpose, a methodological approach was devised for predicting suitable habitat areas for the Cabrera vole by using Boruta Random Forest algorithm [44] and different Sentinel-2-derived data (multispectral data, spectral indices, and textural and diversity indices), topographic variables, and distance to landscape key elements (roads, built-up areas, and water ponds).

\section{Materials and Methods}

\subsection{Study Area}

The study was conducted in a $\sim 176,000$ ha area located in the Alentejo region, Southern Portugal (centroid: 586545 - 4281192; EPSG: 32629-WGS 84/UTM 29N; Figure 1a). The area is characterized by an altitude ranging from 80 to $500 \mathrm{~m}$ a.s.l. with a gently undulating relief [and included within a bioclimatic zone commonly associated to the Cabrera vole, namely the meso-Mediterranean,29]. Climate is typically Mediterranean, with hot and dry summers (August: $31^{\circ} \mathrm{C}$ Tmax), mild and wet winters (January: $6{ }^{\circ} \mathrm{C}$ Tmin), and medium annual rainfall (>600 mm) (Évora 1981-2010 [45]). The landscape is largely dominated by an agrosilvopastoral system called montado (or dehesa), an open woodland of cork (Quercus suber) and/or holm oak (Quercus rotundifolia) trees [46]. The system is characterized by high spatial variability in tree density and an understorey mosaic of annual crops, 
grasslands (intermixed perennial and annual herb communities), and shrublands [47]. While the montado is considered as one of the highest biodiversity-rich ecosystems of the western Mediterranean Basin [48,49] having been classified as a High Nature Value farming system (HNV) [50], it is also referred as one the most threatened in terms of conservation, mainly due to land use intensification [51].

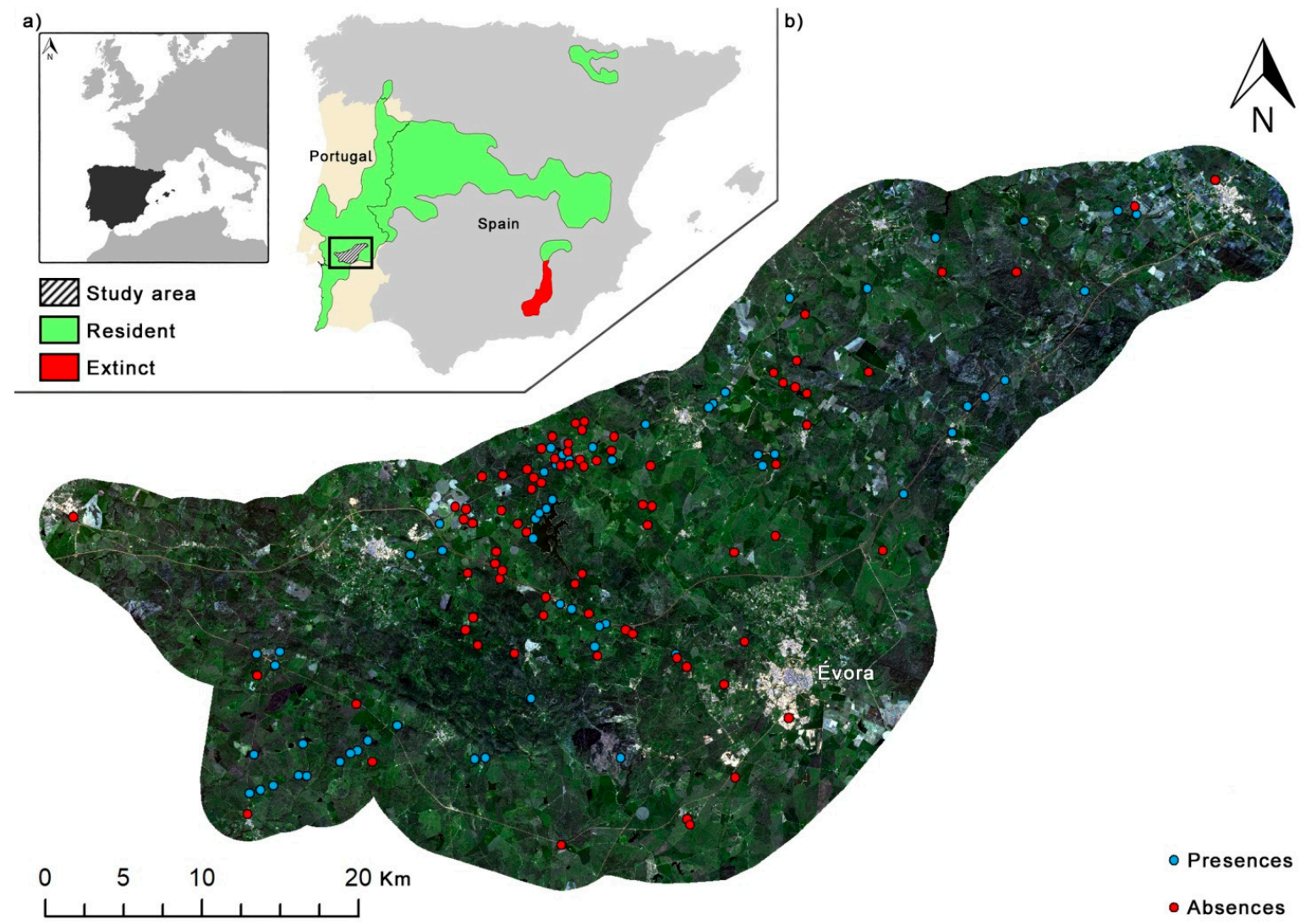

Figure 1. Location of the study area: (a) Iberian Peninsula and actual Cabrera vole distribution range are represented jointly with the study area, located within the Alentejo region (Southern Portugal); and (b) Cabrera vole sampling points layered with the T29SNC, T29SND, T29SPC, and T29SPD Sentinel-2A RGB composite imageries delimited by the study area.

\subsection{Cabrera Vole Field Surveys}

Cabrera vole surveys were conducted through stratified random selection by initially identifying in the field suitable and unsuitable grass patches. A total of 146 patches with dense and tall perennial grasses and/or sedge/rush communities growing in high soil moisture conditions $[13,14]$ were defined as locations of potential occurrence and 79 patches were considered not suitable for the species, due to very dry soil conditions and/or lower cover and height. Each of the selected patches was carefully surveyed by two observers for presence signs typical of this species (surface runways, grass clippings, and typical small, dark green faeces associated with latrines) to assess its presence [14]. These signs are easily recognizable, and together provide a reliable sampling method, at least when other species producing similar signs (e.g., M. agrestis) are absent in the area [11,13], as it is the case of our study region. Each surveyed habitat patch was classified according to the presence/absence of the species, and georeferenced with an accurate GPS device (Garmin eTrex 30x; Projected coordinate system: EPSG: 32629-WGS 84 / UTM 29N; precision up to $3 \mathrm{~m}$ ). The absences were further classified as absences with and without suitable habitat conditions (as the first ones may correspond to patches potentially used by voles, but that were not occupied at the time of the survey); [12]. Although each patch was surveyed once, samplings were conducted in two sessions to account for habitat variation, namely soil humidity, vegetation dryness, and structure. The first session ran in Spring (February-April 2017), which is when 
Cabrera vole populations are typically close to their peaks and breeding activity is presumably higher, due to increased soil humidity and vegetation growth (e.g., green grasses) [14]. The second session was conducted in autumn (October-early December 2018); when soil humidity was significantly lower due to the typical hot and dry summer conditions in the region, which were exceptionally hard and extended in 2018 (IPMA Évora 2018 [45]). This second session was also coincident with the period when more fallow areas can be found, being those of special interest for species' conservation [52]. A total of 97 and 128 herbaceous patches were surveyed in the first and second sessions, respectively. In order to lower model biases, all absences recorded in habitats identified as suitable were discarded from the dataset, as these may have resulted from possible low detectability $[18,26]$. We further applied a $500 \mathrm{~m}$ grid spatial filtering procedure, resulting in a roughly balanced dataset of 62 presences and 79 absences (Figure 1b).

\subsection{Predictor Variables}

Three categories of predictors were defined: (1) Sentinel-2-derived predictors, (2) topographical, and (3) distance to key landscape elements.

\subsubsection{Sentinel-2 Derived Predictor Variables}

To better assess the capability of Sentinel-2 imagery in predicting Cabrera vole habitat suitability areas, three different types of Sentinel-2-derived variables were used: (1) Spectral bands, (2) spectral indices, and (3) textural and diversity indices.

Sentinel-2 multispectral images (Sentinel-2A MSI Level-1C) used in this study were downloaded from the Copernicus Science Data Hub portal (https://scihub.copernicus.eu/dhus/). For each of the study periods, the image with the lowest percentage of clouds was selected to represent environmental conditions at the time of vole surveys (5th April 2017 and 7th October 2018 in the case of the first and second period, respectively). The study area was entirely covered by the union of 4 multispectral images ( $0 \%-1 \%$ of clouds) for each selected period, which followed an atmospheric correction procedure using the Sen2Cor code implemented in the SNAP software [53].

Only the Sentinel-2 bands with 10 and $20 \mathrm{~m}$ spatial resolution were considered in this study, namely the B2 (blue), B3 (green), B4 (red), B5 (Red edge 1), B6 (Red edge 2), B7 (Red edge 3), B8 (NIR1), B8a (NIR2), B11 (SWIR1), and B12 (SWIR2) bands (Table 1).

In order to increase the spatial resolution of the $20 \mathrm{~m}$ spectral bands, a super-resolution enhancement method was applied, whereby high-resolution bands $(10 \mathrm{~m})$ were able to reconstruct coarser $(20 \mathrm{~m})$ at the given resolution while maintaining the associated spectral reflectance, as demonstrated by Brodu [54]. Super-resolved (SR) bands were computed using the Sen2res SNAP plugin (http://step.esa. int/main/third-party-plugins-2/sen2res/).

In order to capture different habitat features that are ecologically relevant to predict suitable areas for the Cabrera vole, three groups of spectral indices were computed: (1) Vegetation biomass indices (NDVI, NDRE1, NDRE2, NDRE3, NDI45, and SATVI), (2) senescent vegetation and soil surface indices (PSRI, SWIR32, and BI2), and (3) vegetation and landscape water content indices (NDII and NDWI) (Table 1). These indices have been successfully used in retrieving different key biophysical vegetation information in semi-arid tree-grass ecosystems such as the one here addressed (montado) [55-59]. 
Table 1. Sentinel-2-derived predictors. The SR abbreviation indicates for which band was applied in the rescaling approach, namely for the Red edge 1, Red edge 2, Red edge 3, the NIR2, SWIR1, and SWIR2 (20m). L = 0.5 was applied in SATVI index.

\begin{tabular}{|c|c|c|c|c|c|}
\hline Group & Type & Code & Description & $\begin{array}{l}\text { Spectral Band or } \\
\text { Equation }\end{array}$ & Reference \\
\hline \multirow{10}{*}{ Spectral Bands } & \multirow{10}{*}{-} & Blue & & B2 & \multirow{10}{*}{ [40] } \\
\hline & & Green & & B3 & \\
\hline & & Red & & B4 & \\
\hline & & Red Edge 1 & & (SR)B5 & \\
\hline & & Red Edge 2 & & (SR)B6 & \\
\hline & & Red Edge 3 & & (SR)B7 & \\
\hline & & NIR 1 & & B8 & \\
\hline & & NIR 2 & & (SR)B8a & \\
\hline & & SWIR1 & & (SR)B11 & \\
\hline & & SWIR2 & & (SR)B12 & \\
\hline \multirow{11}{*}{$\begin{array}{l}\text { Spectral } \\
\text { Indices }\end{array}$} & \multirow{6}{*}{$\begin{array}{l}\text { Vegetation } \\
\text { Biomass } \\
\text { Indices }\end{array}$} & NDI45 & $\begin{array}{l}\text { Normalized Difference } \\
\text { Index } 45\end{array}$ & $\frac{B 5-B 4}{B 5+B 4}$ & [60] \\
\hline & & NDRE1 & $\begin{array}{l}\text { Normalized difference } \\
\text { red edge index } 1\end{array}$ & $\frac{B 8 a-B 5}{B 8 a+B 5}$ & \multirow{3}{*}{ [61] } \\
\hline & & NDRE2 & $\begin{array}{l}\text { Normalized difference } \\
\text { red edge index } 2\end{array}$ & $\frac{B 8 a-B 6}{B 8 a+B 6}$ & \\
\hline & & NDRE3 & $\begin{array}{l}\text { Normalized difference } \\
\text { red edge index } 3\end{array}$ & $\frac{B 8 a-B 6}{B 8 a+B 6}$ & \\
\hline & & NDVI & $\begin{array}{l}\text { Normalized Difference } \\
\text { Vegetation Index }\end{array}$ & $\frac{B 8 a-B 4}{B 8 a+B 4}$ & [62] \\
\hline & & SATVI & $\begin{array}{l}\text { Soil-adjusted Total } \\
\text { Vegetation Index }\end{array}$ & $\frac{(B 11-B 4)}{(B 11+B 4+L)} *(1+L)-\frac{B 12}{2}$ & [63] \\
\hline & \multirow{2}{*}{$\begin{array}{l}\text { Vegetation and } \\
\text { landscape } \\
\text { Water content }\end{array}$} & NDII & $\begin{array}{l}\text { Normalized Difference } \\
\text { Infrared Index }\end{array}$ & $\frac{B 8 a-B 11}{B 8 a+B 11}$ & [64] \\
\hline & & NDWI & $\begin{array}{c}\text { Normalized difference } \\
\text { water index }\end{array}$ & $\frac{B 8 a-B 12}{B 8 a+B 12}$ & [65] \\
\hline & \multirow{3}{*}{$\begin{array}{l}\text { Senescent } \\
\text { vegetation and } \\
\text { soil surfaces } \\
\text { indices }\end{array}$} & PSRI & $\begin{array}{l}\text { Plant Senescence } \\
\text { Reflectance Index }\end{array}$ & $\frac{B 8 a-B 12}{B 8 a+B 12}$ & [66] \\
\hline & & BI2 & $\begin{array}{l}\text { Second Brightness } \\
\text { Index }\end{array}$ & $\frac{\sqrt{(B 4 * B 4)+(B 3 * B 3)+(B 8 * B 8)}}{2}$ & [67] \\
\hline & & SWIR32 & $\begin{array}{l}\text { Shortwave infrared } \\
\text { Reflectance } 3 / 2 \text { ratio }\end{array}$ & $\frac{B 12}{B 11}$ & [68] \\
\hline \multirow{9}{*}{$\begin{array}{l}\text { Textural and } \\
\text { Diversity } \\
\text { Indices }\end{array}$} & \multirow{8}{*}{$\begin{array}{l}\text { Co-occurrence } \\
\text { matrix }\end{array}$} & GLCM_M & Mean & \multirow{8}{*}{$\begin{array}{l}\text { Calculated using the first } \\
\text { principal component (PC1) } \\
\text { with a } 3 \times 3 \text { pixels spatial } \\
\text { moving window in all } \\
\text { directions }\left(0^{\circ}, 45^{\circ}, 90^{\circ},\right. \\
\left.\text { and } 135^{\circ}\right)\end{array}$} & \multirow{8}{*}{ [69] } \\
\hline & & GLCM_Cor & Correlation & & \\
\hline & & GLCM_Con & Contrast & & \\
\hline & & GLCM_D & Dissimilarity & & \\
\hline & & GLCM_E & Entropy & & \\
\hline & & GLCM H & Homogeneity & & \\
\hline & & GLCM S & Second Moment & & \\
\hline & & GLCM_V & Variance & & \\
\hline & Diversity index & Rao's Q & $\begin{array}{l}\text { Rao's quadratic } \\
\text { entropy }\end{array}$ & $\begin{array}{l}\text { Calculated using the } \\
\text { NDVI with a } 3 \times 3 \text { pixels } \\
\text { spatial moving window }\end{array}$ & [70] \\
\hline
\end{tabular}

To describe the montado vegetation and landscape structural and diversity properties, the grey-level co-occurrence matrix (GLCM) [69] and the Rao's Q index [36,70] were calculated, respectively. Prior to the textural calculation, the previously selected spectral bands underwent a Principal Component Analysis (PCA) fusion technique with the aim of obtaining a single Sentinel-2 
image incorporating all bands' information [71]. The principal component image accounting for over the $90 \%$ of bands spectral variability was subsequently used to compute eight GLCM variables, namely, mean, correlation, contrast, Dissimilarity, entropy, homogeneity, second moment, and variance (Table 1). The selected textural variables were calculated using the glcm package (v.1.6.1) [72] implemented in the $R$ (v. 3.5.2) [73], and following the same parametrization settings described in Godinho et al. [57]. The Rao's Q diversity index, which accounts for both the abundance and the pairwise spectral distance among pixels [70], and thus is useful to assess spatial diversity, was calculated by using NDVI as input data and a moving window size of $3 \times 3$ pixels.

\subsubsection{Topographical Predictor Variables}

Four topographical variables (altitude, slope, roughness, and topographic wetness index; Table 2) were derived from a digital elevation model [74] using RSAGA R package (v.1.0.0) [75].

Table 2. Dataset not involving Sentinel-2A images and representing candidate static predictors.

\begin{tabular}{|c|c|c|c|c|}
\hline Group & Type & Denomination & Methodology & Data Source/Reference \\
\hline \multirow{4}{*}{ Topographic } & \multirow{4}{*}{-} & Altitude & - & [74] \\
\hline & & Slope & \multirow{3}{*}{$\begin{array}{c}\text { Calculated from } \\
\text { the Aster (2018) } \\
\text { digital elevation } \\
\text { model }\end{array}$} & \multirow{3}{*}{ [75] } \\
\hline & & Roughness & & \\
\hline & & $\begin{array}{c}\text { Topographic } \\
\text { wetness index }\end{array}$ & & \\
\hline \multirow{3}{*}{ Inference } & \multirow{3}{*}{-} & $\begin{array}{l}\text { Distance to paved } \\
\text { roads }\end{array}$ & \multirow{3}{*}{$\begin{array}{l}\text { Calculated by } \\
\text { applying Euclidean } \\
\text { distance to a } \\
\text { specific landscape } \\
\text { class }\end{array}$} & [76] \\
\hline & & Distance to urban & & \multirow{2}{*}{ [77] } \\
\hline & & $\begin{array}{l}\text { Distance to water } \\
\text { bodies }\end{array}$ & & \\
\hline
\end{tabular}

\subsubsection{Distance to Landscape Elements}

In order to quantify the potential influence of key landscape elements on Cabrera vole spatial distribution (e.g., [14,52]), distances to paved roads, built-up areas, and water bodies were calculated (Table 2). A shapefile containing the information about paved roads was produced using OpenStreetMap data source [76]. Built-up areas and water bodies shapefiles were obtained from the imperviousness and the water and wetness high-resolution layers of the Copernicus Land Monitoring Service [77].

\subsection{Habitat Suitability Model}

The habitat suitability model was built using all previously described predictors using Cabrera vole presence/absence as response variable. The relationship between the predictors and the spatial distribution of Cabrera vole was evaluated in a three-step statistical approach. The first step consisted in selecting the relevant variables from a set of 67 candidate predictors using the Boruta algorithm $[44,78,79]$. Basically, Boruta algorithm relies on an extension of the random forest (RF) [80,81] method by introducing an iterative procedure to compare the relative importance of the original variables with the importance of their randomized copies [44]. After running iteratively a large number of random forest models, the Boruta algorithm computes the mean Z-score value to classify all the variables as confirmed, rejected, or tentative at a predefined threshold of statistical significance (p) and a maximum number of times the algorithm is run (maxRuns) [79]. In this study, the Boruta R package (v.6.0.0) [44] was used to execute the algorithm with maxRuns $=2000$, ntree $=2000$, and p value $=0.01$. The second step consisted of running a Pearson's correlation analysis to determine pairwise correlations within the variables classified as confirmed in the previous step to remove highly correlated $(\mathrm{r}>|0.7|)$ ones. Finally, in the third step, and employing only the uncorrelated most important variables, an RF analysis was used to predict the spatial distribution of Cabrera vole in the study area. For the RF model, the 
number of trees (ntree) was fixed to 2000 and number of variables randomly tested on each split (mtry) to the square root of the number of variables. A 10-fold cross-validation resampling method was used to build the RF model. These analyses were done with the ggRandomForest R package (v.2.0.1) [82]. Each variable relative importance for the model was assessed and partial dependence plots [81] were used to explore interaction effects between variables on Cabrera vole presence probability. Model performance was verified using the area under the curve (AUC) of the Receiver Operator Characteristic (ROC), as well as the proportion of correctly predicted presences and absences [83].

\section{Results}

\subsection{Model Performance}

The Boruta screening procedure resulted in a considerable reduction of possible explanatory variables, as only 26 predictors were confirmed (38.8\% of all the candidate features set, Figure S1). From these, only 11 showed no strong correlation among them $(r<|0.7|)$ and were retained for the multivariate analysis (Figure S2; for more details regarding all pairwise correlation results, see Table S1). The results derived by the 10 -fold cross-validation indicated that the RF model developed was robust given the low estimated error rate percentage, $(19.15 \%)$, determining a high explanatory power of included predictors on the occurrence of the endangered Cabrera vole in our study area (about $80 \%$ of variance explained). Results also showed a 'high' AUC score (area under the curve) of 0.904, a sensitivity (true positive rate) of 0.73 , and a specificity (true negative rate) of 0.778 , therefore a higher performance for correctly predicted absences than presences was noticed.

\subsection{Variable Importance}

Following the multivariate analysis, the "Sentinel-2" variables group showed the highest contribution (65.7\%) in explaining Cabrera vole habitat suitability, comprising 10 variables (Figure 2). The variables from the group "Distance to landscape elements" contributed to explain 34.22\% of the variance, comprising only the distance to paved roads (Figure 2). None of the "Topographic" variables were retained in the final model. Half of "Sentinel-2" variables concerned the Spring period and another half to the Autumn period (Figure 2). The highest significant contributors from the "Sentinel-2" group were "NDI45 (Spring)" (14.9\%), "SWIR1 (Autumn)" (10.4\%), and "Rao's Q (Spring)" $(9.9 \%)$ (Figure 2$)$, meaning these variables incorporated most of the relevant habitat information from remote-sensing data. The habitat suitability for Cabrera vole increased when the spectral vegetation index NDI45 had low-medium values in Spring, and the spectral band SWIR1 and the metric Rao's Q showed intermediate values in Autumn and Spring, respectively (Figure 3c,d). Response curves for "Distance to paved roads" showed that suitability of Cabrera vole steeply decreased with the increase in distance from roads (Figure 3a). The habitat suitability map shows that the occurrence locations fell in high-probability areas in the final habitat suitability model (Figure 4). 


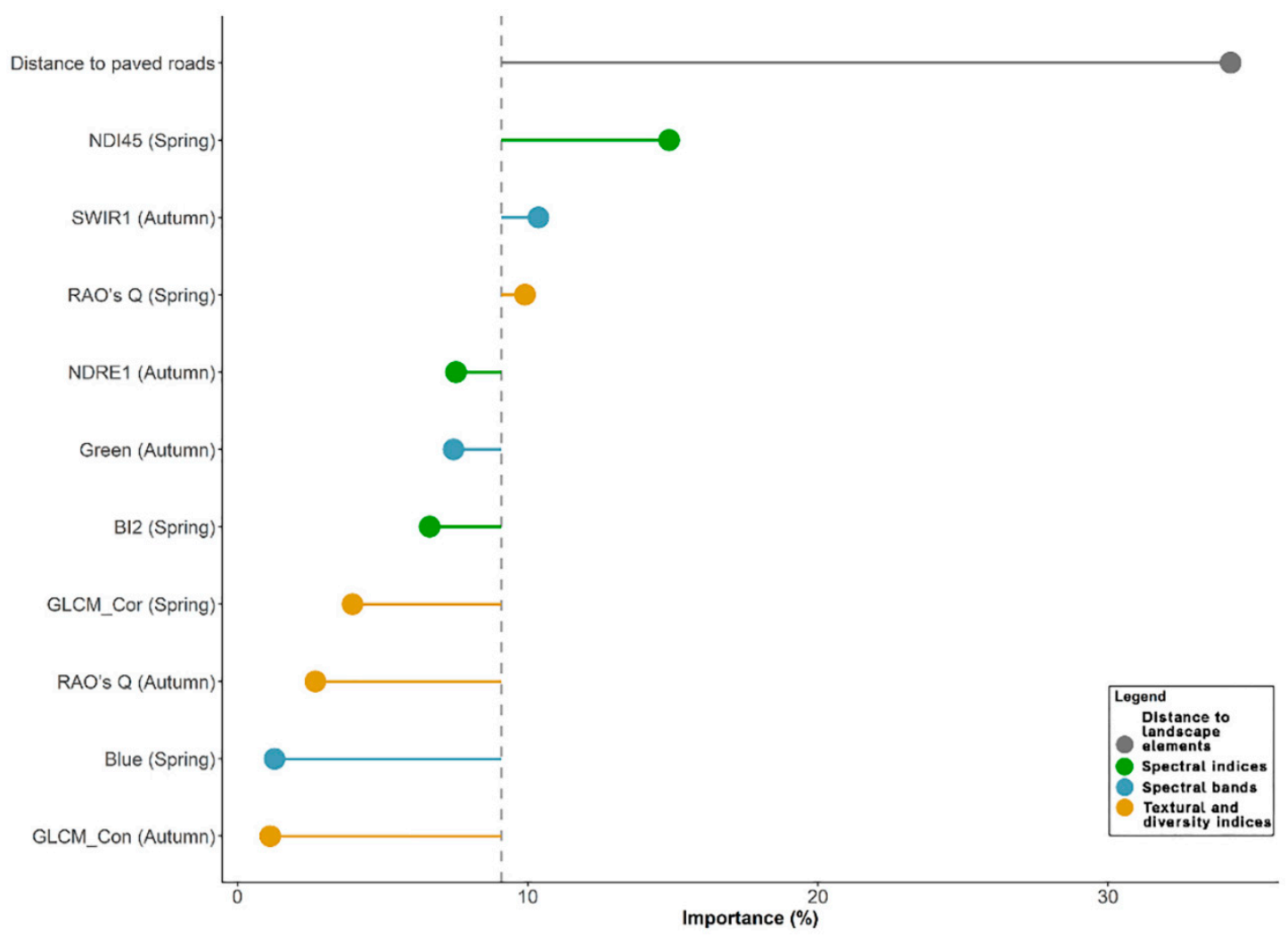

Figure 2. The relative contribution of retained variables (\%) in the final habitat suitability model, layered with respective groups (grey dot: Distance to landscape element; green dots: Spectral indices; cyan dots: Spectral bands; orange dots: Textural and diversity indices) and overlapped with a dashed line representing mean importance value. 

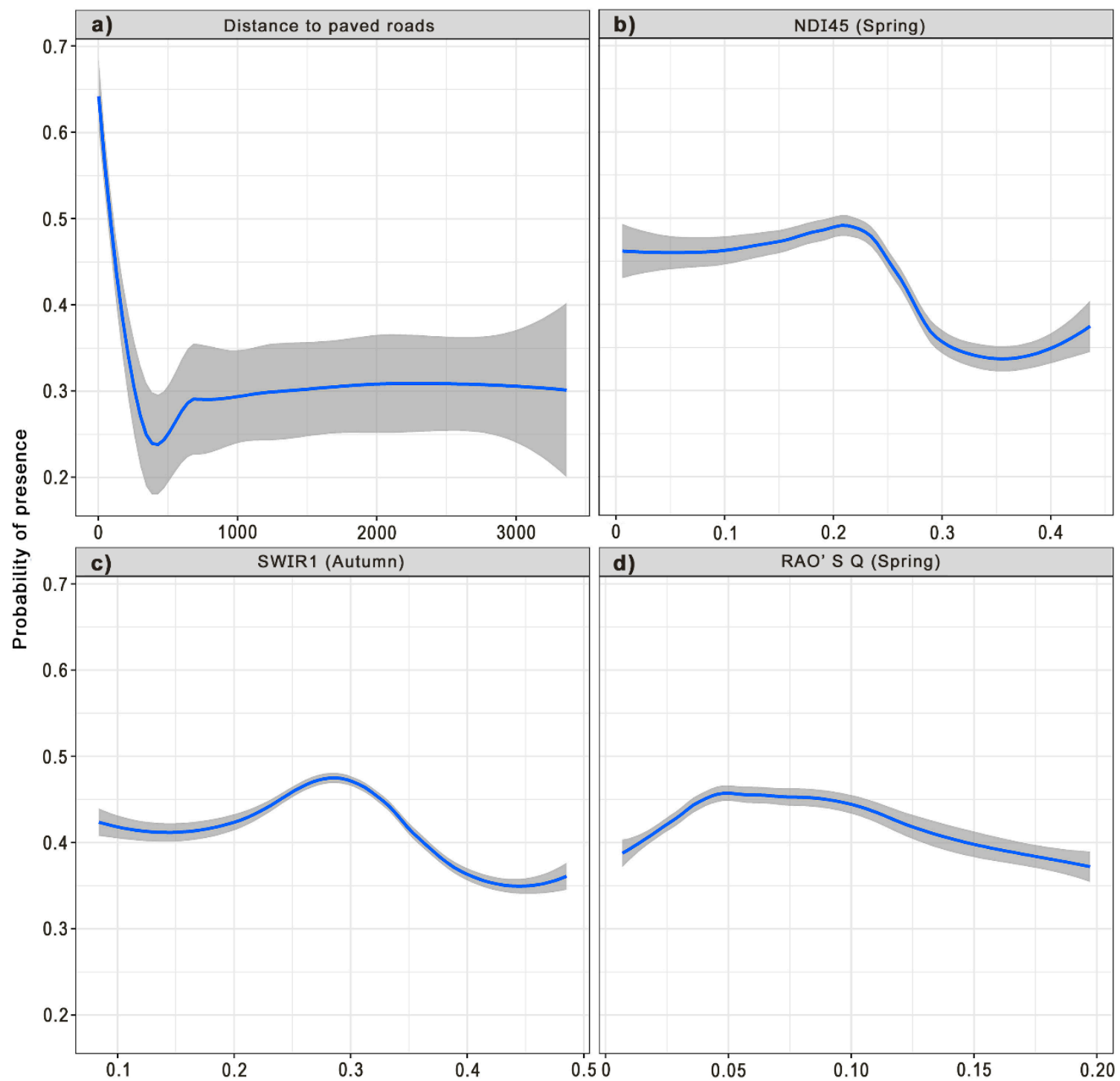

Figure 3. Interactive effects (partial dependence curves) of most important variables: (a) "Distance to paved roads", (b) “NDI45 (Spring)”, (c) “SWIR1 (Autumn)”, and (d) “RAO's Q (Spring)", on probability of Cabrera vole occurrence. The average 10-fold cross-validation results are depicted by the blue lines. The grey area limits \pm standard error. 


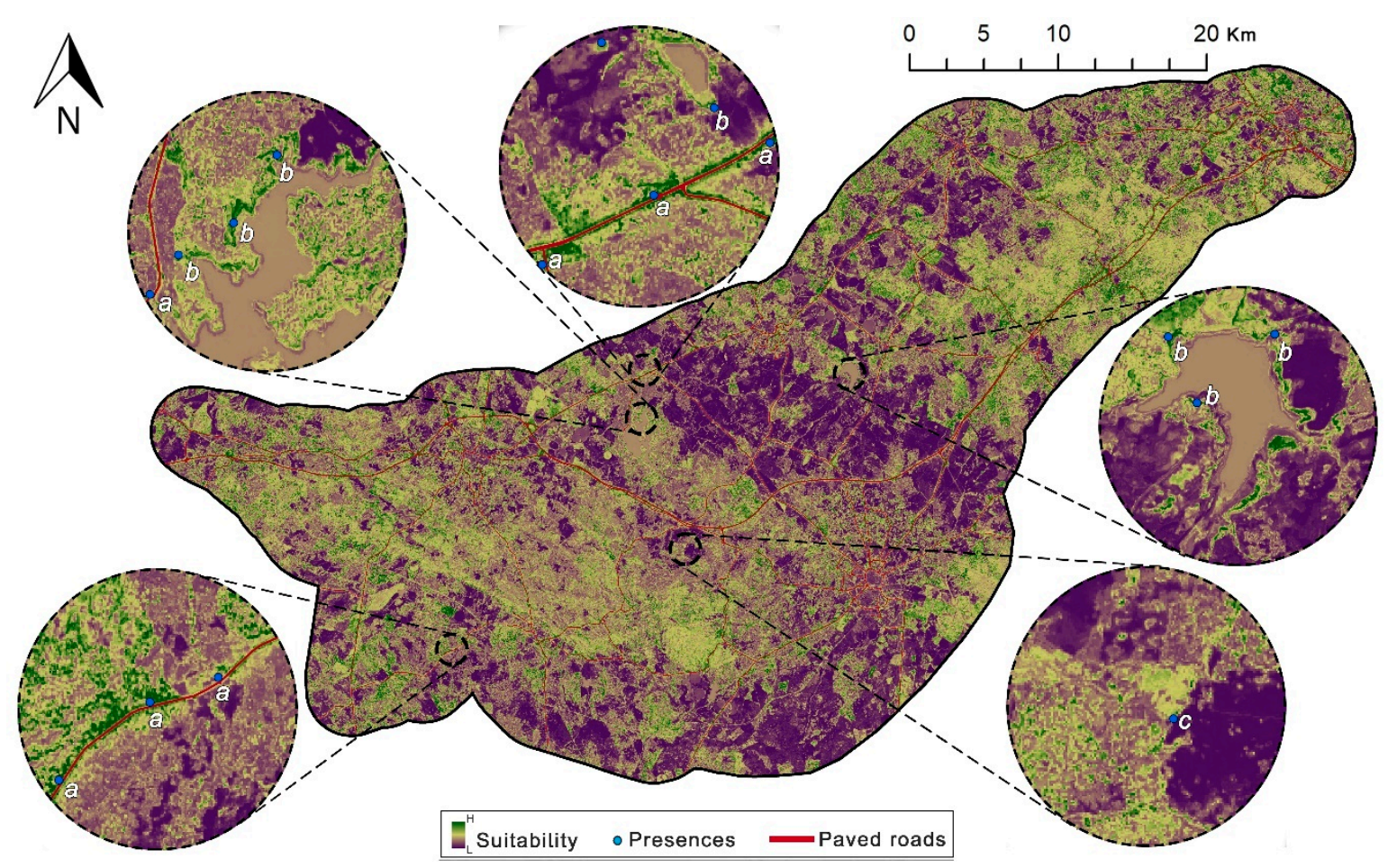

Figure 4. High-resolution Cabrera vole habitat suitability map in Southern part of Portugal, layered with paved roads and presences (blue dots). Zoomed areas are depicted as examples of identified sites of conservation interest namely (a) road verges, (b) pond banks, and (c) field margins. Purple areas: Low suitability; Green areas: high suitability).

\section{Discussion}

Results yielded evidence that fine-scale remote-sensing data may be useful to predict favorable habitats for the occurrence of small-sized species, with small home-ranges and specialized niches in spatially and temporally heterogeneous environments (e.g., [84]). Using ground-data from vole surveys across different periods, we are able to demonstrate that spectral, spatial, and temporal information from Sentinel-2 (Sentinel-2A MSI Level-1C) multispectral images analysis is significantly important to predict the Cabrera vole occurrence.

Results show that NDI45 vegetation index describing areas characterized with low-medium chlorophylls is the most important Sentinel-2-derived proxy for Cabrera vole habitat. High values of this index photosynthetically indicate higher biomass activity, i.e., dense canopies and crops linked to intensified agriculture practices, which are not suitable for the species. On the other hand, very low values of NDI45 indicate increasingly lower soil vegetation cover, which is also not suitable for the species occurrence. Reasons for a higher importance of this index during the 'Spring' should be related to increased wetness and mild temperature conditions during this period, which promotes annual grasses growth, ensuring higher vegetation cover, hence more available resources and improved habitat quality for Cabrera vole [13,14,52]. Multispectral satellite remote-sensing indices (e.g., NDVI) have been proven to successfully explain small mammal species distribution through the use of Landsat 7 [37] and Sentinel-2 data [42]. However, the present study showed that NDI45 is a better predictor than NDVI because it uses spectral information from the red-edge region, which has been recognized to provide more sensitive measurements of vegetation biophysical properties [60,85].

The SWIR1 spectral band obtained from the autumn season was ranked as the third most important variable in predicting Cabrera vole spatial distribution, and, during this season (in particular in 2018; see Section 2.2), the grasslands over the study area were extremely dry due to the exceptional high temperatures and lack of rain. This is noteworthy because in the shortwave infrared region, the 
reflectance reduces as the amount of water content increases in vegetation [32] such that SWIR1 can be sensitive to the existing senescent vegetation in the study area because it reaches a peak in terms of spectral reflectance [65]. Hence, it is reasonable to interpret grassy areas with some moisture conditions as associated with medium values of SWIR1. More specifically, a possible ecological explanation for the better support of SWIR1 during dryer periods is that the Cabrera vole might temporally respond to the leaf senescence spectral signals of perennial grasslands, which may help individuals' survival during most adverse environmental conditions (e.g., [30,52]).

Rao's Q metric is a measure of landscape beta diversity and can be a surrogate for landscape heterogeneity [70]. In the context of study area, the species occurs mainly in small marginal patches embedded in or surrounded by larger forest or agricultural areas, or on road verges [14]. The Rao's Q metric seems to be capturing this landscape diversity signal by showing that the species occurrence is favored in moderately heterogeneous landscapes. This pattern was particularly marked in Spring, when grasses become abundant, vegetation heterogeneity is higher, and vole populations increase given the higher availability of resources [12,16]. By contrast, a low suitability for homogeneous areas emerged from our analysis, suggesting vulnerability to habitat simplification, derived for instance from agricultural intensification or grazing pressure [86], which are known to have major impacts on small mammal habitat specialists [87] and for the Cabrera vole in particular [11]. Reasons for the slight decline in species probability of occurrence at the most heterogeneous areas (higher Rao's Q) are unclear, but may be related to the existence of shrubby areas where predation risk might be greater [11].

Apart from Sentinel-2, Cabrera vole occurrence probability peaks on close proximity to roads. This agrees with previous studies showing that the species often occurs on vegetated road verges, particularly in intensive agricultural or grazed areas [11,13,52]. This result does not necessarily suggest that the species is resilient to the negative effects that roads may exert on wildlife [88]. Instead, it emphasizes the compelling role of road verges in providing refuge habitats and corridors for small mammals, particularly where the surrounding matrix is mostly inhospitable $[11,15,89,90]$. Nevertheless, a major drawback of road verge habitats is that they may induce road-related mortality [91], which should be duly considered when the goal is to promote the use of verges as habitat and/or corridors for biodiversity.

Interestingly, along with the identification of suitable road verges, other semi-natural infrequently managed areas such as banks and field margins were identified in the habitat suitability model (Figure 4). The conservation value of such areas is remarkable, as they usually support high levels of biodiversity, being key elements of High Nature Value farmland [92]. In addition, suitable areas for the Cabrera vole are often associated with Mediterranean temporary ponds [13], which are priority habitats under the EU Habitats Directive. Protecting such areas may be strategic for the conservation of the Cabrera vole, as well other species in human-dominated landscapes with limited availability of suitable habitats. Also, given the spatially limited and scattered distribution of those habitats, proper identification of priority conservation areas to ensure vole' populations viability, can potentially rely on landscape connectivity assessments (e.g., [93]). Once those areas are identified, conservation actions should consider the implementation of agri-environmental schemes, namely in the context of the European Union's Common Agricultural Policy, through which farmers are paid for restoring habitats, for instance by reducing the grazing pressure [11,15,94].

Earlier SDMs developed for Cabrera vole were carried out at broad scales and relied mostly on bioclimatic variables $[10,24]$. Despite the conservation value of macro ecological approaches for mapping environmental suitability at large scales [95], such models do not allow identifying, predicting, and mapping small key habitats [96], and thus are insufficient for defining concrete conservation actions. The use of fine-scale remote-sensing variables may thus provide a cost-effective tool to better support conservation planning with reduced survey costs [36], which may be crucial for rare and vulnerable species $[97,98]$. Higher mapping accuracy, especially when identifying grassland and linear land cover features, could be increased with images possessing very-high spectral and spatial resolutions, namely from data having a resolution spanning around $5 \mathrm{~m}$ of detail, as suggested by 
Thornton et al. [99] and Rapinel et al. [100], possibly fulfilled through fusion of Sentinel 2 data [101]. Nevertheless, the use of very-high resolution data may be prohibitive for SDMs applications over larger areas due to its acquisitions costs. In this context, the use of Sentinel-2 data for habitat suitability mapping should be viewed as an effective compromise between spatial $(10 \mathrm{~m})$ and temporal resolution (5-6 days), as well as its open-data policy. Regarding the statistical methods inherent to SDMs, further studies are recommended in this research field in order to understand the best robustness of approaches able to handle high dimensional data [102], as well addressed to examine the predictive performances of multiple algorithms, especially when concomitantly integrated into an ensemble modeling framework $[18,43]$. This would be particularly interesting when evaluating how sub-sampled group of variables (remote-sensing products, topography, landscape variables) may singularly impact on the performance of species distribution models.

Our findings support the potential of remote sensing for mapping microhabitat suitability of rare small species, which until recently, was largely impracticable due to resource limitations [103]. Sentinel-2 is an open-access resource that provides spatial data at a resolution useful and necessary for this task, and, despite its relatively recent release, effective long-term ecosystem monitoring at local, regional, and national levels is planned to be continuously ensured by this satellite. As such, considering the increasing Sentinel-2 temporal span, future studies on conservation planning incorporating information for longer periods, as it is actually done with other satellites [104], may be valuable because they more likely minimize the common pitfall of assuming stable environmental suitability, and therefore populations persistence, over time $[105,106]$.

\section{Conclusions}

Wildlife habitat selection is increasingly understood through the lens of earth observation remote-sensing instruments, either commercial or open-access. We demonstrated that the use of Sentinel-2-derived habitat variables, incorporating biophysical, spectral, and structural landscape information at fine-scales in different seasons, when integrated into RF machine learning methods, may support the identification of potential favorable areas for small and elusive species in dynamic landscapes. Overall, our study highlights that super-resolved remote-sensing data may provide an important tool for identifying linear habitat features (e.g., [99]). Sentinel-2 may provide high-quality and open-access data for fine-scale conservation planning and population monitoring, which may be particularly adequate when considering patchily distributed, small, rare, and elusive species. Finally, our study supports the view that the integration of detailed remote-sensing data into species distribution models is the next stage for linking species occurrences to environmental conditions at functionally relevant spatio-temporal scales, which is a central issue in ecology and conservation.

Supplementary Materials: The following are available online at http://www.mdpi.com/2072-4292/12/3/562/s1, Figure S1: Boruta feature selection results, Table S1: Pairwise correlation scores between all Confirmed features, Figure S2: Pairwise correlation scores between retained Confirmed features.

Author Contributions: Conceptualization, F.V. and S.G.; data curation, F.V., E.F. and N.F.; formal analysis, F.V.; funding acquisition, A.M. and S.S.; investigation, F.V., S.G. and S.S.; methodology, F.V. and S.G.; project administration, S.S.; supervision, S.G., R.P., A.M. and S.S.; visualization, F.V.; writing-original draft, F.V.; writing-review and editing, F.V., S.G., Ricardo Pita, A.M. and S.S. All authors have read and agreed to the published version of the manuscript.

Funding: F.V. and E.F. were supported by a PhD fellowship, both funded by Fundação para a Ciência e a Tecnologia (SFRH/BD/122854/2016 and SFRH/BD/146037/2019, respectively). This work was also supported by the projects POPCONNECT (PTDC/AAG-MAA/0372/2014) and LIFE LINES (LIFE14 NAT/PT/00108).

Acknowledgments: The authors are grateful to Tiago Mendes, Luis Guilherme Sousa, Tiago Pinto and Pedro Costa for field support.

Conflicts of Interest: The authors declare no conflict of interest. 


\section{References}

1. Ceballos, G.; Ehrlich, P.R.; Barnosky, A.D.; García, A.; Pringle, R.M.; Palmer, T.M. Accelerated modern human-induced species losses: Entering the sixth mass extinction. Sci. Adv. 2015, 1, e1400253. [CrossRef] [PubMed]

2. Lehtonen, A.; Salonen, A.; Cantell, H.; Riuttanen, L.; MacMillan, P. IPBES: Nature's Dangerous Decline 'Unprecedented'; Species Extinction Rates 'Accelerating', Paris, France. Drama and Theatre Education. 26 May 2019. Available online: https://www.ipbes.net/news/Media-Release-Global-Assessment\#_Indigenous_ Peoples,_Local (accessed on 8 May 2019).

3. Newbold, T.; Hudson, L.N.; Hill, S.L.L.; Contu, S.; Lysenko, I.; Senior, R.A.; Börger, L.; Bennett, D.J.; Choimes, A.; Collen, B.; et al. Global effects of land use on local terrestrial biodiversity. Nature 2015, 520, 45-50. [CrossRef] [PubMed]

4. Otto, S.P. Adaptation, speciation and extinction in the Anthropocene. Proc. Biol. Sci. 2018, $285,20182047$. [CrossRef] [PubMed]

5. Ripple, W.J.; Wolf, C.; Newsome, T.M.; Hoffmann, M.; Wirsing, A.J.; McCauley, D.J. Extinction risk is most acute for the world's largest and smallest vertebrates. Proc. Nat. Acad. Sci. USA 2017, 114, 10678-10683. [CrossRef]

6. Brook, B.W.; Sodhi, N.S.; Bradshaw, C.J. Synergies among extinction drivers under global change. Trends Ecol. Evol. 2008, 23, 453-460. [CrossRef]

7. Fernández-Salvador, R. Microtus cabrerae Thomas, 1906, Topillo de Cabrera. In Atlas y Libr Rojo los Mamíferos de España; Palomo, J.L., Gisbert, J., Blanco, J.C., Eds.; Ministerio de Medio Ambiente: Madrid, Spain, 2007; pp. 429-433.

8. Queiroz, A.I.; Alves, P.C.; Barroso, I.; Beja, P.; Fernandes, M.; Freitas, L.; Mathias, M.L.; Mira, A.; Palmeirim, J.M.; Prieto, R.; et al. Microtus cabrerae Rato de Cabrera. In Livro Vermelho dos Vertebrados de Portugal; Cabral, M.J., Ed.; Instituto da Conservação da Natureza: Lisboa, Portugal, 2006; pp. 481-482.

9. Fernandes, M.; Pita, R.; Mira, A. Microtus cabrerae. The IUCN Red List of Threatened Species 2019: E.T13418A90931498. Available online: https://www.iucnredlist.org/species/13418/90931498 (accessed on 18 January 2020).

10. Mira, A.; Marques, C.C.; Santos, S.M.; Rosário, I.T.; Mathias, M.L. Environmental determinants of the distribution of the Cabrera vole (Microtus cabrerae) in Portugal: Implications for conservation. Mamm. Biol. 2008, 2, 102-110. [CrossRef]

11. Pita, R.; Mira, A.; Beja, P. Conserving the Cabrera vole, Microtus cabrerae, in intensively used Mediterranean landscapes. Agric. Ecosyst. Environ. 2006, 115, 1-5. [CrossRef]

12. Pita, R.; Beja, P.; Mira, A. Spatial population structure of the Cabrera vole in Mediterranean farmland: The relative role of patch and matrix effects. Biol. Conserv. 2007, 134, 383-392. [CrossRef]

13. Santos, S.M.; Simões, M.P.; da Luz Mathias, M.; Mira, A. Vegetation analysis in colonies of an endangered rodent, the Cabrera vole (Microtus cabrerae), in southern Portugal. Ecol. Res. 2006, 2, 197-207. [CrossRef]

14. Pita, R.; Mira, A.; Beja, P. Microtus cabrerae (Rodentia: Cricetidae) Mammalian. Species 2014, 46, 48-70. [CrossRef]

15. Ascensão, F.; Santos-Reis, J.F.M. Highway verges as habitat providers for small mammals in agrosilvopastoral environments. Biodivers. Conserv. 2012, 21, 3681-3697. [CrossRef]

16. Santos, S.M.; Mathias, M.; Mira, A.; Simoes, M.P. Vegetation structure and composition of road verge and meadow sites colonized by Cabrera vole (Microtus cabrerae Thomas). Pol. J. Ecol. 2007, 55, 481.

17. Schwartz, M.W.; Cook, C.N.; Pressey, R.L.; Pullin, A.S.; Runge, M.C.; Salafsky, N.; Sutherland, W.J.; Williamson, M.A. Decision Support Frameworks and Tools for Conservation. Conserv. Lett. 2018, 11, 1-12. [CrossRef]

18. Franklin, J. Mapping Species Distributions: Spatial Inference and Prediction (Ecology, Biodiversity and Conservation); Cambridge University Press: Cambridge, UK, 2010. [CrossRef]

19. Guisan, A.; Thuiller, W. Predicting species distribution: Offering more than simple habitat models. Ecol. Lett. 2005, 8, 993-1009. [CrossRef]

20. Razgour, O.; Rebelo, H.; di Febbraro, M.; Russo, D. Painting maps with bats: Species distribution modelling in bat research and conservation. Hystrix 2016, 27, 30-37. 
21. Valerio, F.; Carvalho, F.; Barbosa, A.M.; Mira, A.; Santos, S.M. Accounting for Connectivity Uncertainties in Predicting Roadkills: A Comparative Approach between Path Selection Functions and Habitat Suitability Models. Environ. Manag. 2019, 64, 329-343. [CrossRef]

22. Tulloch, A.I.T.; Sutcliffe, P.; Naujokaitis-Lewis, I.; Tingley, R.; Brotons, L.; Ferraz, K.M.P.M.B.; Possingham, H.; Guisan, A.; Rhodes, J.R. Conservation planners tend to ignore improved accuracy of modelled species distributions to focus on multiple threats and ecological processes. Biol. Conserv. 2016, 199, 157-171. [CrossRef]

23. Valerio, F.; Basile, M.; Balestrieri, R.; Posillico, M.; Di Donato, S.; Altea, T.; Matteucci, G. The reliability of a composite biodiversity indicator in predicting bird species richness at different spatial scales. Ecol. Indic. 2016, 71, 627-635. [CrossRef]

24. Mestre, F.; Pita, R.; Paupério, J.; Martins, F.M.S.; Alves, P.C.; Mira, A.; Beja, P. Combining distribution modelling and non-invasive genetics to improve range shift forecasting. Ecol. Modell. 2015, 297, 171-179. [CrossRef]

25. Rebelo, H.; Jones, G. Ground validation of presence-only modelling with rare species: A case study on Barbastella barbastellus (Chiroptera: Vespertilionidae). J. Appl. Ecol. 2010, 47, 410-420. [CrossRef]

26. Robinson, O.J.; Ruiz-Gutierrez, V.; Fink, D. Correcting for bias in distribution modelling for rare species using citizen science data. Divers. Distrib. 2018, 24, 460-472. [CrossRef]

27. He, K.S.; Bradley, B.A.; Cord, A.F.; Rocchini, D.; Tuanmu, M.-N.; Schmidtlein, S.; Turner, W.; Wegmann, M.; Pettorelli, N. Will remote sensing shape the next generation of species distribution models? Remote Sens. Ecol. Conserv. 2015, 1, 4-18. [CrossRef]

28. Leitão, P.J.; Santos, M.J. Improving Models of Species Ecological Niches: A Remote Sensing Overview. Front. Ecol. Evol. 2019, 7, 1-7. [CrossRef]

29. Rivas-Martínez, S. Les étages bioclimatiques de la végétation de la Péninsule Ibérique. Anales del Jardín Botánico de Madrid 1981, 37, 251-268.

30. Rosário, I.T.; Cardoso, P.E.; da Luz Mathias, M. Is habitat selection by the Cabrera vole (Microtus cabrerae) related to food preferences? Mamm. Biol. 2008, 73, 423-429. [CrossRef]

31. Coops, N.C.; Wulder, M.A. Breaking the Habit(at). Trends Ecol. Evol. 2019, 34, 585-587. [CrossRef] [PubMed]

32. Jones, H.G.; Vaughan, R.A. Remote Sensing of Vegetation: Principles, Techniques, and Applications; Oxford University Press: New York, NY, USA, 2011; ISBN 978-0-19-920779-4.

33. Pettorelli, N.; Ryan, S.; Mueller, T.; Bunnefeld, N.; Jedrzejewska, B.; Lima, M.; Kausrud, K. The Normalized Difference Vegetation Index (NDVI): Unforeseen successes in animal ecology. Clim. Res. 2011, 46, 15-27. [CrossRef]

34. Pettorelli, N.; Vik, J.O.; Mysterud, A.; Gaillard, J.-M.; Tucker, C.J.; Stenseth, N.C. Using the satellite-derived NDVI to assess ecological responses to environmental change. Trends Ecol. Evol. 2005, 9, 503-510. [CrossRef]

35. Oeser, J.; Heurich, M.; Senf, C.; Pflugmacher, D.; Belotti, E.; Kuemmerle, T. Habitat metrics based on multi-temporal Landsat imagery for mapping large mammal habitat. Remote Sens. Ecol. Conserv. 2019, 1-18. [CrossRef]

36. Randin, C.F.; Ashcroft, M.B.; Bolliger, J.; Cavender-Bares, J.; Coops, N.C.; Dullinger, S.; Dirnböck, T.; Eckert, S.; Ellis, E.; Fernández, N.; et al. Remote Sensing of Environment Monitoring biodiversity in the Anthropocene using remote sensing in species distribution models. Remote Sens. Environ. 2020, 239, 111626. [CrossRef]

37. Vaniscotte, A.; Pleydell, D.R.; Raoul, F.; Quéré, J.P.; Jiamind, Q.; Wang, Q.; Tiaoying, L.; Bernarda, N.; Coeurdassier, M.; Delattre, P.; et al. Modelling and spatial discrimination of small mammal assemblages: An example from western Sichuan (China). Ecol. Model. 2009, 220, 1218-1231. [CrossRef] [PubMed]

38. Leyequien, E.; Verrelst, J.; Slot, M.; Schaepman-Strub, G.; Heitkonig, I.M.A.; Skidmore, A. Capturing the fugitive: Applying remote sensing to terrestrial animal distribution and diversity. Int. J. Appl. Earth Obs. 2007, 9, 1-20. [CrossRef]

39. Kumar, S.; Simonson, S.E.; Stohlgren, T.J. Effects of spatial heterogeneity on butterfly species richness in Rocky Mountain National Park, CO, USA. Biodivers. Conserv. 2009, 18, 739. [CrossRef]

40. Berger, M.; Moreno, J.; Johannessen, J.A.; Levelt, P.F.; Hanssen, R.F. ESA's sentinel missions in support of Earth system science. Remote Sens. Environ. 2012, 120, 84-90. [CrossRef]

41. Drusch, M.; Bello, U.; del Carlier, S.; Fernandez, V.; Gascon, F.; Hoersch, B.; Isola, C.; Laberinti, P.P. Sentinel-2: ESA' s Optical High-Resolution Mission for GMES Operational Services. Remote Sens. Environ. 2012, 120, 25-36. [CrossRef] 
42. Andreo, V.; Belgiu, M.; Andreo, V.; Belgiu, M.; Hoyos, D.B.; Osei, F.; Provensal, C.; Stein, A. Ecological Informatics Rodents and satellites: Predicting mice abundance and distribution with Sentinel-2 data. Ecol. Inform. 2019, 51, 157-167. [CrossRef]

43. Arenas-Castro, S.; Gonçalves, J.; Alves, P.; Alcaraz-Segura, D.; Honrado, J.P. Assessing the multi-scale predictive ability of ecosystem functional attributes for species distribution modelling. PLoS ONE 2018, 13, e0199292. [CrossRef]

44. Kursa, M.B.; Rudnicki, W.R. Feature Selection with the Boruta Package. J. Stat. Softw. 2010, 36, 1-13. Available online: http://www.jstatsoft.org/v36/i11/ (accessed on 2 April 2019). [CrossRef]

45. IPMA. Instituo Português do Mar e da Atmosfera. Normais Climatológicas 2019, 675, 1981-2010. Available online: http://www.ipma.pt/pt/index.html (accessed on 25 February 2019).

46. Pinto-Correia, T.; Ribeiro, N.; Sá-Sousa, P. Introducing the montado, the cork and holm oak agroforestry system of southern Portugal. Agrofor. Syst. 2011, 82, 99-104. [CrossRef]

47. Joffre, R.; Rambal, S.; Ratte, J.P. The dehesa system of southern Spain and Portugal as a natural ecosystem mimic. Agrofor. Syst. 1999, 45, 57. [CrossRef]

48. Branco, O.; Bugalho, M.; Silva, L.N.; Barreira, R.; Vaz, P.; Días, F. Hotspot Areas for Biodiversity and Ecosystem Services in Montados-HABEaS. WWF Mediterr. Programme Port. 2010, 55.

49. Díaz-Villa, M.D.; Marañón, T.; Arroyo, J.; Garrido, B. Soil seed bank and floristic diversity in a forest-grassland mosaic in southern Spain. J. Veg. Sci. 2003, 5, 701-709. [CrossRef]

50. Oppermann, R.; Beaufoy, G.; Jones, G. High Nature Value Farming in Europe. 35 European Countries-Experiences and Perspectives; Verlag Regionalkultur: Ubstadt-Weiher, Germany, 2012.

51. Pinto-Correia, T.; Godinho, S. Chapter 4 Changing Agriculture-Changing Landscapes: What is Going on in the High Valued Montado. In Agriculture in Mediterranean Europe: Between Old and New Paradigms; Emerald Group Publishing Limited: Bingley, UK, 2013; pp. 75-90.

52. Proença-Ferreira, A.; Ferreira, C.; Leitão, I.; Paupério, J.; Sabino-Marques, H.; Barbosa, S.; Lambin, X.; Alves, P.C.; Beja, P.; Moreira, F.; et al. Drivers of survival in a small mammal of conservation concern: An assessment using extensive genetic non-invasive sampling in fragmented farmland. Biol. Conserv. 2019, 230, 131-140. [CrossRef]

53. European Space Agency, 2018. SNAP_Version 6.0.0. Available online: http://step.esa.int/main/ (accessed on 14 March 2019).

54. Brodu, N. Super-resolving multiresolution images with band-independent geometry of multispectral pixels. IEEE Trans. Geosci. Remote Sens. 2017, 55, 4610-4617. [CrossRef]

55. Fragoso-Campón, L.; Quirós, E.; Mora, J. Overstory-understory land cover mapping at the watershed scale: Accuracy enhancement by multitemporal remote sensing analysis and LiDAR. Environ. Sci. Pollut. Res. 2019, 27, 1-14. [CrossRef]

56. Godinho, S.; Guiomar, N.; Machado, R.; Santos, P.; Sá-Sousa, P.; Fernandes, J.P.; Neves, N.; Pinto-Correia, T. Assessment of environment, land management, and spatial variables on recent changes in montado land cover in southern Portugal. Agrofor. Syst. 2016, 1, 177-192. [CrossRef]

57. Godinho, S.; Guiomar, N.; Gil, A. Estimating tree canopy cover percentage in a mediterranean silvopastoral systems using Sentinel-2A imagery and the stochastic gradient boosting algorithm. Int. J. Remote Sens. 2018, 39, 4640-4662. [CrossRef]

58. Hill, T.C.; Williams, M.; Bloom, A.A.; Mitchard, E.T.A.; Ryan, C.M. Are inventory based and remotely sensed above-ground biomass estimates consistent? PLOS ONE 2013, 8, e74170. [CrossRef]

59. Serrano, J.; Shahidian, S.; Marques da Silva, J.; Carvalho, M. Proximal and remote sensing to evaluate the impact of climatic inter-annual irregularity in montado Mediterranean ecosystems-a case study. In Proceedings of the 3rd Agriculture and Climate Change Conference, Budapest, Hungary, 24-27 March 2019.

60. Delegido, J.; Verrelst, J.; Alonso, L.; Moreno, J. Evaluation of Sentinel-2 Red-Edge Bands for Empirical Estimation of Green LAI and Chlorophyll Content. Sensor 2011, 11, 7063-7081. [CrossRef]

61. Navarro, G.; Caballero, I.; Silva, G.; Parra, P. Evaluation of forest fire on Madeira Island using Sentinel-2A MSI imagery. Int. J. Appl. Earth Obs. Geoinf. 2017, 58, 97-106. [CrossRef]

62. Rouse, J., Jr.; Haas, R.H.; Schell, J.A.; Deering, D.W. Monitoring vegetation systems in the Great Plains with ERTS. NASA Special Publ. 1974, 351, 309. 
63. Marsett, R.C.; Qi, J.; Heilman, P.; Biedenbender, S.H.; Watson, M.C.; Amer, S.; Weltz, M.; Goodrich, D.; Marsett, R. Remote sensing for grassland management in the arid southwest. Rangel. Ecol. Manag. 2006, 59, 530-540. [CrossRef]

64. Hardisky, M.A.; Klemas, V.; Smart, R.M. The influence of soil salinity, growth form, and leaf moisture on the spectral radiance of Spartina alterniflora canopies. Photogram Eng. Remote Sens. 1983, 49, 77-83.

65. Gao, B. NDWI A Normalized Difference Water Index for Remote Sensing of Vegetation Liquid Water from Space. Remote Sens. Environ. 1996, 266, 257-266. [CrossRef]

66. Merzlyak, M.N.; Gitelson, A.A.; Chivkunova, O.B.; Rakitin, V.Y. Non-destructive optical detection of pigment changes during leaf senescence and fruit ripening. Physiol. Plant. 1999, 106, 135-141. [CrossRef]

67. Escadafal, R. Remote sensing of arid soil surface color with Landsat thematic mapper. Adv. Space Res. 1989, 9, 159-163. [CrossRef]

68. Guerschman, J.P.; Hill, M.J.; Renzullo, L.J.; Barrett, D.J.; Marks, A.S.; Botha, E.J. Estimating fractional cover of photosynthetic vegetation, non-photosynthetic vegetation and bare soil in the Australian tropical savanna region upscaling the EO-1 Hyperion and MODIS sensors. Remote Sens. Environ. 2009, 113, 928-945. [CrossRef]

69. Haralick, R.M.; Shanmugam, K.; Dinstein, I. Textural Features for Image Classification. IEEE Trans. Syst. Man. Cybern. 1973, 6, 610-621. [CrossRef]

70. Rocchini, D.; Marcantonio, M.; Ricotta, C. Measuring Rao's Q diversity index from remote sensing: An open source solution. Ecol. Indic. 2017, 72, 234-238. [CrossRef]

71. Schulte to Bühne, H.; Pettorelli, N. Better together: Integrating and fusing multispectral and radar satellite imagery to inform biodiversity monitoring, ecological research and conservation science. Methods Ecol. Evol. 2018, 9, 849-865. [CrossRef]

72. Zvoleff, A. Glcm: Calculate Textures from Grey-Level Co-Occurrence Matrices (GLCMs) R Package Version 3.5.0. 2016. Available online: https://CRAN.R-project.org/package=glcm (accessed on 12 December 2018).

73. R Development Core Team, R. A Language and Environment for Statistical Computing. R Foundation for Statistical Computing; R Development Core Team R: Vienna, Austria, 2018; ISBN 3-900051-07-0. Available online: http://www.R-project.org (accessed on 10 November 2017).

74. ASTER GDEM. 2018. Available online: https://asterweb.jpl.nasa.gov/gdem.asp (accessed on 11 May 2018).

75. Brenning, A.; Bangs, D.; Becker, M. RSAGA: SAGA Geoprocessing and Terrain Analysis. R package Version 1.0.0. 2018. Available online: https://CRAN.R-project.org/package=RSAGASdfsdf (accessed on 11 May 2018).

76. OpenStreetMap Contributors. 2018. Europe OpenStreetMap Data. Available online: https://download. geofabrik.de/europe/portugal.html (accessed on 5 February 2018).

77. European Union, Copernicus Land Monitoring Service 2018, European Environment Agency (EEA). Available online: https://land.copernicus.eu/ (accessed on 19 May 2018).

78. Gichenje, H.; Pinto-correia, T.; Godinho, S. Remote Sensing Applications: Society and Environment An analysis of the drivers that affect greening and browning trends in the context of pursuing land degradation-neutrality. Remote Sens. Appl. Soc. Environ. 2019, 15, 100251. [CrossRef]

79. Kursa, M.B.; Rudnicki, W.R. The all relevant feature selection using random forest. arXiv 2011, arXiv:1106.5112Sdfsdf.

80. Breiman, L.E.O. Random Forests. Machin. Learn. 2001, 45, 5-32. [CrossRef]

81. Evans, J.S.; Murphy, M.A.; Holden, Z.A.; Cushman, S.A. Modeling Species Distribution and Change Using Random Forest; Springer: New York, NY, USA, 2011; pp. 139-159. [CrossRef]

82. Ehrlinger, J. ggRandomForests: Visually Exploring Random Forests. R Package Version 2.0.1. 2016. Available online: https://CRAN.R-project.org/package=ggRandomForests (accessed on 18 April 2019).

83. Fielding, A.H.; Bell, J.F. A review of methods for the assessment of prediction errors in conservation presence/absence models. Environ. Conserv. 1997, 24, 38-49. [CrossRef]

84. Carrié, R.; Lopes, M.; Ouin, A.; Andrieu, E. Bee diversity in crop fields is influenced by remotely-sensed nesting resources in surrounding permanent grasslands. Ecol. Indic. 2018, 90, 606-614. [CrossRef]

85. Dube, T.; Mutanga, O.; Adam, E.; Ismail, R. Intra-and-Inter Species Biomass Prediction in a Plantation Forest: Testing the Utility of High Spatial Resolution Spaceborne Multispectral RapidEye Sensor and Advanced Machine Learning Algorithms. Sensors 2014, 14, 15348-15370. [CrossRef]

86. Almeida, M.; Azeda, C.; Guiomar, N.; Pinto-correia, T. The effects of grazing management in montado fragmentation and heterogeneity. Agrofor. Syst. 2016, 90, 69-85. [CrossRef] 
87. Serafini, V.N.; Priotto, J.W.; Gomez, M.D. Effects of agroecosystem landscape complexity on small mammals: A multi-species approach at different spatial scales. Landsc. Ecol. 2019, 8, 1-13. [CrossRef]

88. Coffin, A.W. From roadkill to road ecology: A review of the ecological effects of roads. J. Transp. Geogr. 2007, 15, 396-406. [CrossRef]

89. Jumeau, J.; Boucharel, P.; Handrich, Y. Road-related landscape elements as a habitat: A main asset for small mammals in an intensive farming landscape. Basic Appl. Ecol. 2017, 25, 15-27. [CrossRef]

90. de Redon, L.; Le Viol, I.; Jiguet, F.; Machon, N.; Scher, O.; Kerbiriou, C. Road network in an agrarian landscape: Potential habitat, corridor or barrier for small mammals? Acta Oecol. 2015, 62, 58-65. [CrossRef]

91. Silva, C.; Simões, M.P.; Mira, A.; Santos, S.M. Factors influencing predator roadkills: The availability of prey in road verges. J. Environ. Manag. 2019, 247, 644-650. [CrossRef] [PubMed]

92. Almeida, M.; Pinto-Correia, T. Exploring the use of landscape as the basis for the identification of High Nature Value farmland: A case-study in the Portuguese Montado. In Proceedings of the 10th European IFSA Symposium on Producing and Reproducing Farming Systems: New Modes of Organisation for Sustainable Food Systems of Tomorrow, Aarhus, Denmark, 1-4 July 2012; p. 7.

93. Merrick, M.J.; Koprowski, J.L. Circuit theory to estimate natal dispersal routes and functional landscape connectivity for an endangered small mammal. Landsc. Ecol. 2017, 32, 1163-1179. [CrossRef]

94. Donald, P.F.; Evans, A.D. Habitat connectivity and matrix restoration: The wider implications of agri-environment schemes. J. Appl. Ecol. 2006, 43, 209-218. [CrossRef]

95. Rapacciuolo, G. Strengthening the contribution of macroecological models to conservation practice. Global. Ecol. Biogeogr. 2019, 28, 54-60. [CrossRef]

96. Gottschalk, T.K.; Aue, B.; Hotes, S.; Ekschmitt, K. Influence of grain size on species-habitat models. Ecol. Model. 2011, 222, 3403-3412. [CrossRef]

97. Guisan, A.; Broennimann, O.; Engler, R.; Vust, M.; Yoccoz, N.G.; Lehmann, A.; Zimmermann, N.E. Using Niche-Based Models to Improve the Sampling of Rare Species. Conserv. Biol. 2006, 20, 501-511. [CrossRef]

98. Mi, C.; Huettmann, F.; Guo, Y.; Han, X.; Wen, L. Why choose Random Forest to predict rare species distribution with few samples in large undersampled areas? Three Asian crane species models provide supporting evidence. PeerJ 2017, 5, e2849. [CrossRef]

99. Thornton, M.W.; Atkinson, P.M.; Holland, D.A. A linearised pixel-swapping method for mapping rural linear land cover features from fine spatial resolution remotely sensed imagery. Comput. Geosci. 2007, 33, 1261-1272. [CrossRef]

100. Rapinel, S.; Mony, C.; Lecoq, L.; Lecoq, L.; Clément, B.; Thomas, A.; Hubert-Moy, L. Evaluation of Sentinel-2 time-series for mapping floodplain grassland plant communities. Remote Sens. Environ. 2019, 223, 115-129. [CrossRef]

101. Pereira, O.J.R.; Melfi, A.J.; Montes, C.R. Image fusion of Sentinel-2 and CBERS-4 satellites for mapping soil cover in the Wetlands of Pantanal. Int. J. Image Data Fusion 2017, 8, 148-172. [CrossRef]

102. Speiser, J.L.; Miller, M.E.; Tooze, J.; Ip, E. A comparison of random forest variable selection methods for classification prediction modeling. Expert Syst. Appl. 2019, 134, 93-101. [CrossRef]

103. Engler, J.O.; Stiels, D.; Schidelko, K.; Strubbe, D.; Quillfeldt, P.; Brambilla, M. Avian SDMs: Current state, challenges, and opportunities. J. Avian. Biol. 2017, 48, 1483-1504. [CrossRef]

104. Bishop-taylor, R.; Broich, M. Evaluating static and dynamic landscape connectivity modelling using a 25-year remote sensing time series. Landsc. Ecol. 2018, 33, 625-640. [CrossRef]

105. Milanesi, P.; Della Rocca, F.; Robinson, R.A. Integrating dynamic environmental predictors and species occurrences: Toward true dynamic species distribution models. Ecol. Evol. 2019, 10, 1-6. [CrossRef]

106. Arenas-Castro, S.; Regos, A.; Gonçalves, J.F.; Alcaraz-Segura, D.; Honrado, J. Remotely Sensed Variables of Ecosystem Functioning Support Robust Predictions of Abundance Patterns for Rare Species. Remote Sens. 2019, 11, 2086. [CrossRef]

(C) 2020 by the authors. Licensee MDPI, Basel, Switzerland. This article is an open access article distributed under the terms and conditions of the Creative Commons Attribution (CC BY) license (http://creativecommons.org/licenses/by/4.0/). 